日臨外会誌 $68(10) ， 2651-2654 ， 2007$

症例

抜去困難の腹腔内ドレーンを腹腔鏡下手術で抜去した 1 例 呉共済病院外科

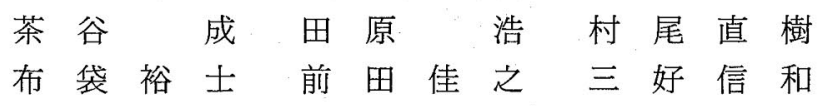

症例は 43 歳, 女性. S 状結腸癌に対して S 状結腸切除, 虫垂切除を施行し, その際, 左下腹部からダグラス窩ヘプリーツドレーンを挿入した。術後経過は良好で, 術後第 6 病日にドレーンを抜去しょうとしたところ，抜去の途中で抵抗があり，また疼痛の訴え があったため, 抜去を断念した。 その後も抵抗拉よび疼痛の訴えのため, ドレーンを抜 去することができなかった。諸検査から，ドレーン抜去困難の原因として，ドレーン内 腔への腹腔内脂肪組織の嵌入が推測された。術後第 9 病日, 腹腔鏡下手術でドレーンを 抜去した. 大網がドレーン側孔からドレーン内腔に嵌入していたため，大網を引き出し てドレーンを抜去した。その後, 腹腔内組織の損傷および出血の有無を十分に観察して 手術を終了した，術後経過は良好であり，初回手術より術後第14病日に退院した．本症 例では腹腔鏡下に腹腔内の観察を十分に行うことができ, 安全にドレーンを抜去するこ とができた。

索引用語：ドレーン抜去困難，腹腔鏡

緒言

ドレナージは外科臨床上, 最も重要な基本手技の一 つであるが，ドレーン留置に伴う合併症も数多く報告 されている(1) 3). 今回, われわれは $\mathrm{S}$ 状結腸切除後に腹 腔内ドレーン抜去困難となり, 腹腔鏡下手術でドレー ンを抜去した1例を経験したので，文献的考察を加え て報告する。

\section{症例}

患者: 43歳, 女性.

主訴：腹腔内ドレーン衰引時の疼痛.

既往歴：2000年，右声带ポリープ手術．2006年，左 声帯ポリープ手術.

現病歴：2007年 4 月, S 状結腸癌に対して開腹手術 にてS 状結腸切除, 虫垂切除を施行した。その際, 左 下腹部からダグラス简ヘプリーツドレーンを挿入し た. 術後経過は良好で, 術後第 4 病日に食事を開始し た. 術後第6病日にドレーンを抜去しようとしたとこ ろ, ドレーンを $5 \mathrm{~cm}$ 引き抜いたところで抵抗があり,

2007 年 6 月 5 日受付 2007 年 7 月 12 日採用 〈所属施設住所〉

干737-8505 呉市西中央 $2-3-28$
また疼痛の訴えがあったため, 抜去を途中で断念した。 術後第 7 病日，再度ドレーン抜去を試みるも，前日と 同様, 抵抗と疼痛の訴えがあり, 抜去できなかった。 術後第 8 病日,ドレーン内腔に脂肪組織を認めたため, 脂肪組織の嵌入を解除する目的で，ドレーン内腔に気 管内チューブ用スタイレットを挿入しながらドレーン を变引するも，やはり抵抗抢よび疼痛のため抜去でき なかった。

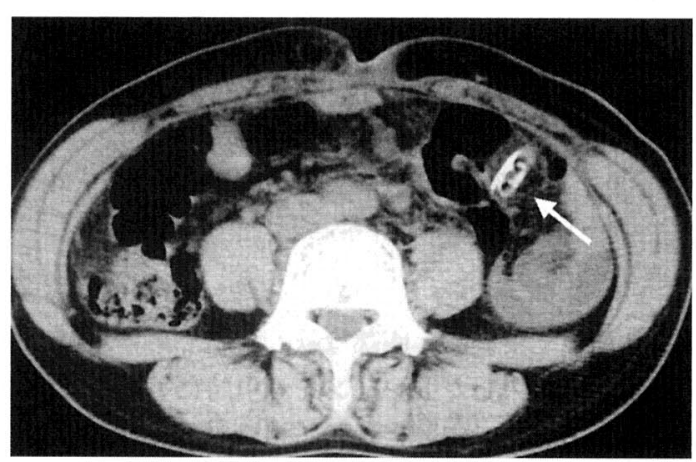

図 1 腹部 CT 検査所見：ドレーン (矢印) 周囲には明ら かな腫瘤や膿瘍はなく, 脂肪組織のみであった.ドレー ン内に腸管が嵌入した所㒻はなかった。 


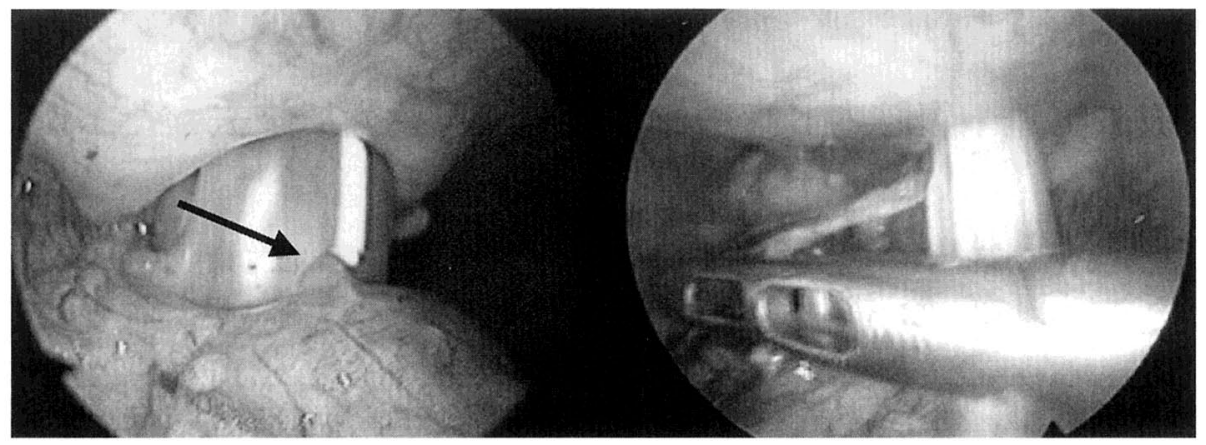

a

b

図 2 手術所見 $1 ： a$ ）ドレーン側孔（矢印）からドレーン内鄄に脂肪組織が嵌入していた，b) 脂肪組織をドレーン側孔から引き出した。

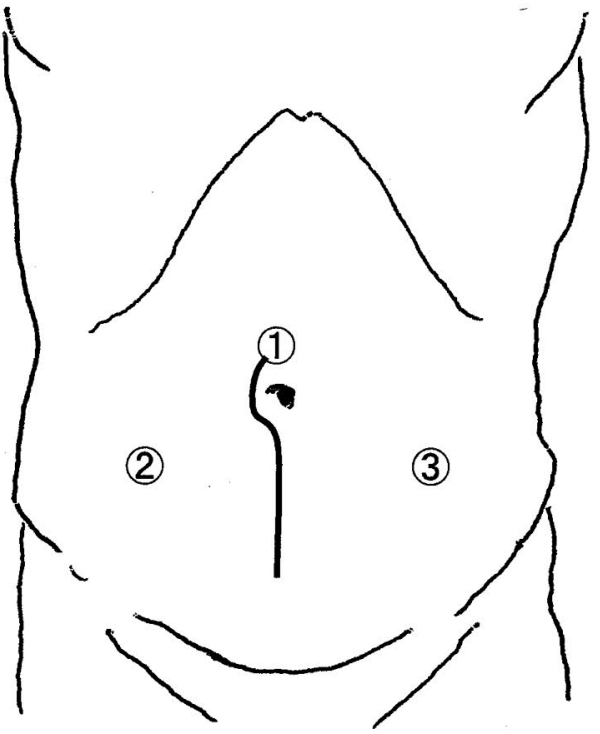

\section{図 3 手術所見 2}

(1) S 状結腸切除時の正中創上部に $5 \mathrm{~mm}$ ポート を挿入し, カメラを挿入した.

(2)右下腹部に $5 \mathrm{~mm}$ ポートを挿入し，鉗子を挿入 した.

(3)左下腹部のドレーン抜去部に $5 \mathrm{~mm}$ ポートを 挿入し，鉗子を挿入した。

身体所見 : 安静時, 腹部は軟, 平坦であったが, 左 下腹部から挿入したドレーンを牽引時に著明な疼痛を 訴えた。ドレーン内腔には脂肪組織が認められた。

血液生化学所見：特記すべき異常は認められなかっ た。

腹部 CT 検査所見：ドレーン周囲には明らかな腫瘤
や膿瘍はなく，脂肪組織のみであった。ドレーン内に 腸管が嵌入した所見はなかった（図1）。

以上より，ドレーン抜去困難の原因は，ドレーン内 腔への腹腔内脂肪組織の嵌入ではないかと推測され た. 術後第 9 病日, ドレーン抜去時の腹腔内組織の損 傷および出血の有無の観察を十分に行うため, 全身麻 酔下に腹腔鏡下手術でドレーンを抜去した。

手術所見：S 状結腸切除時の正中創上部に $5 \mathrm{~mm}$ ポートを挿入し，気腹したのち，カメラをポートから 挿入して腹腔内を観察したところ，ドレーン側孔から ドレーン内腔に脂肪組織が嵌入していた(図 $2 a$ ).ド レーン内腔にポートの内筒を挿入して嵌入解除を試み るも，解除できなかったため，右下腹部に $5 \mathrm{~mm}$ ポー トを挿入し，鉗子を挿入して脂肪組織をドレーン側孔 から引き出した(図 2 b). ドレーンを抜去後, ドレー ン抜去部に $5 \mathrm{~mm}$ ポートを挿入し(図3)，鉗子を挿入 して計 2 本の鎾子を用いて腹腔内を観察し，嵌入して いた脂肪組織は大網であることを確認した．また，出 血および腸管・腸間膜の損傷がないことを確認した。

術後経過：術後経過は良好であり，初回手術より術 後第14病日に退院した。

\section{考察}

ドレナージは手術の基本的な手技の一つである．腹 部消化器外科領域でのドレーン挿入には, 以下の 3 つ の目的がある4). (1)後出血や縫合不全などの術直後の 腹腔内の異常な病態をいち早く知るための情報ドレナ ージ (Information drainage)，(2)腹腔内浸出液貯留を 排除し, 腹腔内感染, 膿瘍形成を予防するための予防 的ドレナージ (Prophylactic drainage), (3)腹腔内に 既に膿汁や消化液が貯留している場合の救命治療のた 
めの治療的ドレナージ（Therapeutic drainage）であ る、ドレナージは体内に異物を挿入するため合併症も 少なくなく，腹腔内ドレーンに関する合併症として腸 穿孔，瘦孔形成，創感染，出血，脱落，ヘルニア，抜 去困難やイレウスなどの報告がある(1)5).

ドレーン抜去困難の報告は稀であり，われわれが検 索しえた限り, 本邦では過去に丸尾ら ${ }^{6)}$ の 1 例, 藤田 $ら^{1)} 3$ 例, 佐藤ら ${ }^{7} の 1$ 例が報告されているのみであ る. 丸尾ら ${ }^{6)}$ の報告は, 膵頭十二指腸切除時に膵空腸吻 合部下縁に挿入したデュープルドレーンが抜去困難と なり，胆道鏡にてドレーン側孔からの脂肪組織の嵌入 が認められ，鈷子で脂肪組織を押し込みながらドレー ンを抜去したというものであった。また，藤田ら ${ }^{11} の$ 報 告は，腹膜炎手術時のドレナージにおいて用いられた ドレーン総数 351 本のうち 3 例にシリコンドレーンの 拔去困難が認められ，いずれもドレーンに縦に割を入 れて大網を腹腔内に押し戻してドレーンを抜去したと いうものであった。また，佐藤らうの報告は，絞扼性イ レウス手術時にダグラス窩と右傍結腸窩に留置したプ リーツドレーンが両方とも抜去困難となり，前者が自 然抜去された後，後者を全身麻酔下に抜去したもので あった．同症例ではドレーン刺入部に皮膚切開を追加 してドレーンを少しずつ引き抜いたところ，ドレーン 側孔から嵌入した索状物が，ドレーン内腔を閉塞して いた大網と癒着していることが判明し，この索状物を 切離することでドレーンが抜去された。

上記のように，抜去困難の機序として，大網がドレ ーンの内腔に入り込むために起こると考元られる．佐 藤ら ${ }^{7)}$ の報告では, 抜去困難に陥った機序を, (1)メイン ルートに大網などが入り込むことによって同ルートが 閉塞する，(2)ドレーン側孔のみを通じてドレナージが 行われる. (3)このドレナージルートを通じて側孔から 大網などに索状物が入り込み，(4)ドレーン内腔に詰ま った大網と癒着する，と推察している。また, Agrama ら ${ }^{8)}$ は側孔のあるドレーンを長期間腹腔内に入れてお くと大網がチューブの内腔に入り込み抜去困難となる と警告している.

ドレーン抜去困難を予防するためには，蓮見ら ${ }^{4)} の$ 言うように，ドレーンを不要となり次第，ただちに抜 去することが有効であると思われるが，本症例のよう にドレーンを長期留置しなかった症例でも, 大網がド レーン側孔からドレーン内腔に嵌入し，抜去困難をき
たすことがありうる。佐藤ら7は，ドレーン挿入時，側 孔から大網が入り込んでもよいように、主ドレーン孔 から側孔に向けて縦に割を入れる方法を提示してお り, 現時点でドレーン抜去困難に対する有効な予防策 の一つであると思われる。

実際にドレーン拔去困難に至った場合，暴力的操作 を行うと出血や臟器損傷をきたす危険性があり，ドレ ーン抜去に際しては，より安全な方法が必要である. 本症例のように，ドレーン拔去困難に対して腹腔鏡下 手術でドレーンを抜去した症例は検索しえた限り過去 にはないが，ドレーン抜去時の腹腔内組織の損傷およ び出血の有無の観察を十分に行うことができ，有効な 方法であると思われた。

\section{結 語}

$\mathrm{S}$ 状結腸切除後に腹腔内ドレーン拔去困難となり, 腹腔鏡下手術でドレーンを抜去した 1 例を報告した。 ドレーン抜去困難症例では暴力的操作により出血や臓 器損傷をきたす危険性があるが，本症例では腹腔鏡下 に腹腔内の観察を十分に行うことができ，安全にドレ ーンを抜去することができた。

\section{文献}

1）藤田哲二, 又井一雄, 桜井健司：腹膜炎手術後の ドレナージトラブル，腹部救急譶療の進歩 9 ： 551--554, 1989

2) Hee RV : Complications of drainage. Acta Chir Belg 83: 340-344, 1983

3）碓井昌：腹腔ドレナージ施行の実際. 臨看 $10: 797-806,1984$

4）蓮見昭武, 岡本喜一郎, 若山敦司他：腹腔内ドレ ーンの功罪. 消外 $22 ： 413-417 ， 1999$

5）吉田奎介，川合千尋，清水武昭：ドレナージの原 則とドレーンの種類。臨外 $48: 429-434,1993$

6）丸尾啓敏，久米進一郎：腹腔内ドレーン抜去困難 に対しドレーン内胆道鏡操作が有効であった 1 例。日腹部救急医会誌 $19: 801,1999$

7）佐藤耕一郎，加藤丈人，玉橋信彰他：腹腔内ドレ ーン抜去困難症例に対して診断，治療に難渋した 1例. 臨外 $61: 355-359,2006$

8) Agrama HM, Blackwood JM, Brown CS, et al: Functional longevity of intraperioneal drains: an experimental evaluation. Am J Surg 132 : 418-421, 1976 


\title{
A CASE OF LAPAROSCOPIC REMOVAL OF A DRAINAGE TUBE AFTER ABDOMINAL SURGERY
}

\author{
Naru CHATANI, Ko TAHARA, Naoki MURAO, \\ Hiroshi HOTEI, Yoshiyuki MAEDA and Nobukazu MIYOSHI \\ Department of Surgery, Kure Kyosai Hospital
}

A 43-year-old woman underwent sigmoidectomy and appendectomy for cancer of the sigmoid colon when a pleat drain was inserted from the left lower abdomen to the Douglas' pouch. The patient's postoperative course was uneventful. On the $6^{\text {th }}$ postoperative day we attempted to remove the drain but had to abandon the attempt, because we encountered resistance to the removal on the way and the patient complained of pain. Further efforts of removing the drain were unsuccessful due to the resistance and her complaint of pain. Following various examinations, it was inferred that incarceration of abdominal fatty tissue into the drain's lumen might cause the difficulty in removing it. Thus laparoscopy-assisted surgery to remove the drain was performed on the $9^{\text {th }}$ postoperative day. During surgery we saw that the greater omentum had been incarcerated from the side opening of the drain to its lumen, so that we pulled out the greater omentum and removed the drain. After carefully observed the presence or absence of injuries to the intra-abdominal tissues and hemorrhage, we completed the surgery. The postoperative course was uneventful and the patient was discharged from the hospital on the $14^{\text {th }}$ postoperative day.

In this case we were able to observe the abdominal cavity carefully and remove the drain safely by employing laparoscopy-assisted operation. 